\title{
The Architecture of Eco-Theology: Towards a New Typology for Christian Sacred Space
}

\section{Roberto Chiotti}

Citation: Chiotti, Roberto. 2022. The Architecture of Eco-Theology: Towards a New Typology for Christian Sacred Space. Religions 13: 29. https://doi.org/10.3390/ rel13010029

Academic Editor: Tammy Gaber

Received: 6 December 2021

Accepted: 23 December 2021

Published: 29 December 2021

Publisher's Note: MDPI stays neutral with regard to jurisdictional claims in published maps and institutional affiliations.

Copyright: (C) 2021 by the author. Licensee MDPI, Basel, Switzerland. This article is an open access article distributed under the terms and conditions of the Creative Commons Attribution (CC BY) license (https:/ / creativecommons.org/licenses/by/ $4.0 /)$.
Founding Principal, Larkin Architect Limited, 238 Broadview Avenue, 2nd Floor, Toronto, ON M4M 2G7, Canada; roberto@larkinarchitect.com

\begin{abstract}
This paper will begin by exploring the underlying scriptural and theological foundations for a Christian response to the ecological crisis with particular focus on the writings of cultural historian, Father Thomas Berry, CP. It will then describe the first worship space in Canada that attempts to embody the emergent "Eco-theology" to invoke both the transcendental and imminent presence of the divine by reconsidering every design decision from first principles. As articulated in its architecture, the traditional elements of Roman Catholic sacred space have been re-imagined and given unique expression to emphasize that when we gather for Christian worship, we do so within the greater context of creation. St. Gabriel's Passionist Parish church therefore represents a distinctly new typology for Christian Worship that contributes towards an understanding of early scriptural teachings which emphasized the sacredness of all creation and not just the sacredness of humankind. The new building as sacred space presents a "Gestalt whole", and like the medieval cathedrals of Europe, becomes itself a form of Catechetical pedagogy, engaging the senses, demanding reflection, and inviting transformation.
\end{abstract}

Keywords: sacred space; worship spaces; eco-theology; cosmology; phenomenology of religion; phenomenology of architecture; creation spirituality; climate change; design for the sacred

\section{Introduction}

This contribution to the Religions Special Issue: Sacred Spaces: Designing for the Transcendental, will begin by exploring the underlying theological foundations for a Christian response to the ecological crisis with particular focus on the teachings of Roman Catholic Passionist priest, Father Thomas Berry, CP. The paper will then describe the complex design process undertaken to realize the first worship space in Canada that attempts to embody his emergent "Eco-theology" in ways that invoke both the transcendent and imminent presence of the divine. As articulated in the architecture of St. Gabriel's Passionist Parish church, the traditional elements and current liturgical norms of Roman Catholic sacred space have been re-imagined and given unique expression to emphasize that when we gather for Christian worship, we do so within the greater context of creation. From the introduction of divergent iconic forms, to the integration of state-of-the-art sustainable design strategies such as passive solar heating and cooling, water harvesting, incorporation of a living wall, the dramatic use of natural light in combination with colored glass skylights, and mechanical systems modeled after natural earth systems, the architecture represents a distinctly new typology for Christian Worship that contributes towards an understanding of early church teachings which emphasized the sacredness of all creation and not just the sacredness of humankind. The new building as sacred space presents a "Gestalt whole", and like the medieval cathedrals of Europe, becomes itself a form of Catechetical pedagogy, engaging the senses and inviting transformation.

\section{Eco-Theology: A Christian Response to the Ecological Crisis}

For eco-theologians, both scripture and creation are revelatory of the divine. They have re-discovered that early Christians, the saints and the great reformers of the church 
have written eloquently about creation, emphasizing its ability to provide deep spiritual instruction about the nature of God. Frederick Krueger, in his book A Cloud of Witnesses: The Deep Ecological Legacy of Christianity, provides many references to support this view. The following are just a few:

"Creation reveals Him who formed it, and the very work made suggests Him who made and ordered it". St. Irenaeus of Lyon (129-203)

"I want creation to penetrate you with so much admiration that wherever you go the least plant may bring you a clear remembrance of the Creator ... One blade of grass or one speck of dust is enough to occupy your entire mind in beholding the art with which it has been made." St. Basil the Great (347-407)

"The whole earth is a living icon of the face of God." St. John Damascene (675-749)

"God writes the Gospel, not in the Bible alone, but also on trees, and in the flowers and clouds and stars." Martin Luther (1483-1546) (Krueger 2002)

Similarly, Thomas Berry in his Dream of the Earth quotes a passage from Thomas Aquinas' Summa Theologica, to reflect this understanding.

" ... because the divine goodness 'could not be adequately represented by one creature alone, He produced many diverse creatures, that what was wanting in one in the representation of the divine goodness might be supplied by another. For goodness, which in God is simple and uniform in creatures is manifold and divided; and hence the whole universe together participates the divine goodness more perfectly, and represents it better than any single creature whatever.' From this we could argue that the community of all the components of the planet Earth is primary in the divine intention." (Berry 1988, p. 79)

Berry can be seen as consistent with this long tradition of spirituality that stimulated ancient theologians to read the "book of nature" along with the book of the bible in their worship. However, his vision is inspired by recent empirical scientific knowledge of the Universe and the Earth that was unavailable to these earlier Christian mystics and theologians. Berry's descriptive prowess infuses the technical realities associated with the evolution of the universe into a poetic, epic narrative that is both alluring and transformative:

"The story of the universe is the story of the emergence of a galactic system in which each new expression emerges through the urgency of self-transcendence. Hydrogen in the presence of some millions of degrees of heat emerges into helium. After the stars take shape as oceans of fire in the heavens, they go through a sequence of transformations. Some eventually explode into the stardust out of which the solar system and the earth take shape. Earth gives unique expression of itself in its rock and crystalline structures and in the variety and splendor of living forms, until humans appear as the moment in which the unfolding universe becomes conscious of itself. The human emerges not only as an earthling, but also as a worldling. We bear the universe in our beings and the universe bears us in its being. The two have a total presence to each other and to that deeper mystery out of which both the universe and ourselves have emerged." (Berry 1988, p. 132)

Berry also compares this identity to the "anthropic principle" as expressed by physicists:

"In this perception the human is seen as a mode of being of the universe as well as a distinctive being in the universe. Stated somewhat differently, the human is that being in whom the universe comes to itself in a special mode of conscious reflection." (Berry 1988, p. 16)

This contradicts the Biblical cosmology that set humans apart from everything else and enabled us to imagine having dominion over the Earth. By contrast, the new cosmology suggests that what we do to the Earth, we do to ourselves and, by extrapolation, what we do to the universe, we do to ourselves. For ecologist Michael Dowd: 
"The scientist looking through a telescope is literally the universe looking at itself.

The child entranced by the immensity of the ocean is Earth enraptured by itself.

The student learning biology is the planet consciously learning about how it has functioned unconsciously for billions of years." (Dowd 1991, p. 17)

This sense of humans as having emerged as the self-reflective consciousness of the universe begs us to consider our relationship to everything else in the universe beyond ourselves. According to Berry:

"The scientist in the depths of the unconscious is drawn by the mystical attraction of communion with the emerging creative process. This would not be possible unless it were a call of subject to subject, if it were not an effort at total selfrealization on the part of the scientists." (Berry 1988, p. 133)

To invoke a more visceral response, Berry recites the poetic words of his colleague and friend, Brian Swimme: "The universe shivers with wonder in the depths of the human" (Berry 1988, p. 16). The concept of cosmogenesis suggests that certain form-producing dynamics have guided the universe in its 14 billion years of time-developmental evolution. Swimme and Berry have characterized these creative dynamics as inner spontaneities governed by the primordial orderings of differentiation, subjectivity, and communion:

"These orderings are real in that they are efficacious in shaping the occurrences of events and thereby establishing the overriding meaning of the universe. Indeed, the very existence of the universe rests on the power of this ordering. Were there no differentiation, the universe would collapse into a homogeneous sludge; were there no subjectivity, the universe would collapse into inert, dead extension; were there no communion, the universe would collapse into isolated singularities of being." (Berry and Swimme 1992, pp. 72-73)

According to Berry, these principles, which were understood by our primal ancestors as intuitive processes, are now understood by scientific reasoning. However, the significance of their implications for how we relate to the universe and more poignantly Earth has yet to be fully understood or acted upon in any effective manner (Berry 1988, p. 44).

\section{An Architect's Journey towards Embracing the Eco-Theology of Thomas Berry, C.P.}

As Tammy Gaber, Academic Editor for this Special Issue suggests, the lived experience and design process that underpins our sacred spaces are often overlooked or underrepresented in the texts and publications that seem to remain focused on aesthetics, or at best, the cultural context of a particular religious structure. The task of responding to the eco-theology of Father Thomas Berry, C.P., in a tangible, realistic, and meaningful way through the design of a new church for the St. Gabriel's Passionist Parish had no precedent and therefore, as architects, we had to consider every design decision from first principles. As such, the iterative design process lasting close to eight years in duration became as important as the final built solution, both of which were further influenced by contemporary liturgical norms for Catholic worship spaces and the many "real world" factors that students of architecture are most often able to ignore. A complex, lengthy municipal approvals process, ongoing engagement with internal and external stakeholders, negotiations with the developer who purchased the surplus land, the adversarial political agenda of a local municipal councilor, budgetary constraints and inflationary pressures within the construction industry precipitated by the urgent construction infrastructure required to host the Olympics in the far away city of Beijing, China, all had their impacts on the ways in which the design evolved.

\section{Parallel Challenges for the Passionist Community}

But even before the idea of a new church had been contemplated, many decades in the evolution of the Passionist Congregation's ministry in Canada paralleled the author's own faith journey before just the right circumstances would align to make the project a 
possibility. This was a privileged time for absorbing the deep eco-spirituality of Thomas Berry.

After somewhat fitful beginnings, the Passionist's in Canada purchased farmland on Sheppard Avenue north of Toronto. Cardinal James McGuigan, Archbishop of Toronto, was looking for help from religious congregations to establish new parishes to serve the burgeoning suburban Catholic community. Ground was broken for a new 500 seat church and attached seminary on 1 April 1952. Over the next several decades, St. Gabriel's became a thriving parish. Later, in 1965, Bishop Emmett Carter of London, Ontario invited the Passionists to establish a foundation within his diocese. The Passionists purchased a farmhouse with several out buildings on 55 acres of land located on the Canadian north shore of Lake Erie near Port Burwell where they developed a retreat ministry.

By 1979, the retreat leadership at Holy Cross Retreat Centre had embraced the teachings of fellow Passionist Father Thomas Berry, CP, who in 1978 first published his pathbreaking essay The New Story where he looked to science and the humanities to jointly narrate the great epic of evolution as the way forward to ensure a viable future for humans and the planet (Angyal et al. 2019, p. 128). The newly christened "Holy Cross Centre for Ecology and Spirituality", was dedicated to learning the emerging subject of Eco-theology and featured an annual colloquium organized by Father Stephen Dunn, CP and Cenacle Sister Anne Lonergan, highlighting Berry in conversation with guest speakers from a diversity of backgrounds from the theological, political, scientific, arts, and indigenous communities to name just a few. Visitors from across Canada, the United States and abroad would gather at the centre for these annual colloquia. "Dunn, who had met and been inspired by Thomas during their time together at Immaculate Conception Monastery in the mid-1950s, was now a professor of theology at St. Michael's College at the University of Toronto and had become a major supporter of Thomas's work" (Angyal et al. 2019, p. 128).

\section{Events That Capture the Vision}

In the interim, it was as a student of theology pursuing a graduate degree at University of St. Michael's College that I met Father Stephen Dunn, CP who, as the director of the Elliott Allen Institute for Theology and Ecology (EAITE), introduced me to the work of Thomas Berry through his course on Environmental Ethics and later more deeply as part of a pastoral residency program at Holy Cross Centre. Early on in my part time studies, while still engaged in a full-time architectural practice, two pivotal events helped to definitively shift my focus towards eco-theology and commit to enrollment in the EAITE.

The first of these was an opportunity in 1990 to attend a symposium hosted at the Ontario Institute for Studies in Education featuring Thomas Berry as keynote speaker. Listening about the earth through the eyes of Thomas Berry was both inexplicably and simultaneously alluring and disorienting, so I defer once again to the expressive words of Brian Swimme in his forward for The Dream of the Earth:

"Colors reveal unsuspected hues, and not all of them are soothing; sounds swell with new meanings, but not all of them are comforting; human actions bespeak hitherto unimaginable significance, but not all of it is complimentary. But in both pleasure and pain, the Earth folds back more intimately on itself through this vision. In the magic of these words, we capture a glimpse of an unseen and unsuspected Earth beauty. We find ourselves seized by the conviction that we have made our way to a creative wellspring of the Earth adventure." (Berry 1988, p. ix)

The second was an opportunity to visit the Centre for Ecology and Spirituality at Port Burwell for the first time. While completing our studies at University of Toronto, my partner Kimberly and I began attending worship services at the Newman Centre, the Catholic ministry on Campus. In preparation for Easter of 1991, Heather Eaton, one of several doctoral students who had recently graduated from EAITE, announced to the parish that she would lead a Lenten Retreat at the Centre. For three days in March, immersed in the raw beauty of the Centre's natural landscape, Eaton helped us to explore ways in which 
we could integrate into our daily lives Berry's invitation to bring about a more mutuallyenhancing human relationship with the earth. The sense of urgency was heightened by images of the Kuwait oil wells afire and spewing thick black smoke across the desert, a consequence of Iraq's "scorched earth" policy as they retreated during the Gulf War. ${ }^{1}$ Juxtaposed to this devastation was the discovery of thousands of red wing blackbirds that had arrived on their spring migratory return to Canada prematurely.

These formative experiences also prompted my partner and I to henceforth attend the annual colloquia where we were able to deepen our understanding of and commitment to the values of eco-theology from the many new insights that inevitably emerged from Thomas Berry's conversations with invited guests and to eventually respond to the call to serve as lay associates in support of the Centre's mission. For many summers, Holy Cross Centre became our second home. Time spent within the four distinct and interconnected ecosystems of beach, marsh, meadow, and forest within the bounds of the Centre's property, helped to inform the meaning of sacred landscape and the sense of divine presence afforded by immersion in the natural world. Flocks of migrating tundra swans that would magically fly overhead during outdoor liturgies combined with thousands of monarch butterflies that would gather in the trees of the property before continuing their arduous journey south over the lake all seemed to reinforce the understanding that this place was indeed holy ground. In conversation with Berry, the staff of the Centre had created a series of modest outdoor mediation sites that were located and arranged within these ecosystems to serve as a contemplative pilgrimage honoring the Universe Story.

"In Berry's terminology, these were profound readings of the cosmic 'scriptures of the earth'. They highlighted eight irreversible transformations within the Evolutionary Epic: four of the macro universe, four of the earth's evolution once the human emerged." (Dunn 2010, p. 72)

On a smaller scale, these eight stations were represented in stained glass windows that adorned the glass house chapel of the Centre's main house overlooking the meadow where we would gather for the celebration of the eucharist.

It was here at the Centre, with about one hundred people gathered around them in 1992, that Berry, along with his co-author and creative collaborator of ten years, physicist, Brian Swimme, launched their book The Universe Story. This epic narrative brought fulfilment to Berry's desire to provide humans with a compelling story that would shift us away from the allurement of unsustainable consumption and provide the necessary inspiration for restoring our relationship to the earth. (Angyal et al. 2019, p. 120)

Berry tells of how publishing The Universe Story seemed to sum up his whole career of spiritual and cultural enquiry:

"This was the culmination of my childhood concern for the beauty and grandeur and wonder of the world. My study of indigenous peoples and their remarkable sensitivity to the surrounding universe, my study of the great classical civilizations, my study of western culture: all conformed to the same understanding-the immersion of the human in the world of nature was also immersion in the world of the sacred. Every being of planet Earth, even of the entire universe, was participant in the grand liturgy of the universe that I had for so many years celebrated in my earlier years of monastic seclusion." (Angyal et al. 2019, p. 122)

Meanwhile, after participating in a "Mission Fulfillment Weekend Retreat"2, I was invited to serve on the Worship and Liturgy Commission for the Passionist's St. Paul of the Cross Province in the US, of which the Congregation of Canadian Passionists was a Vicariate. One of the commission's first tasks was to prepare the liturgies for the upcoming Provincial Chapter ${ }^{3}$ which was being held at a venerable old hotel in the Poconos during the spring of 1998. As a member of the team, I was encouraged to attend all the proceedings with the exception of participating in the election of the new Provincial and his leadership team, which understandably, was available only to vowed members of the Passionist Congregation. 
For me, the years of seeking the architect's grasp of sacred space would now become uniquely manifest in a special experience with the Passionists. With this time alone, I decided to take a walk in the surrounding woods, eventually finding a trail that led to the valley below where I found a stream gently meandering beneath the forest floor. I was drawn by the sound of the flowing water to find a rock in its midst in order to rest and enjoy the freshness of the spring landscape that was bursting with new life. As my eyes were drawn to the light overhead being filtered through the verdant green of the emerging forest canopy, I came to realize that I was encountering one of those profound experiences that constellate a heightened sensitivity and deep connection to the natural world. This prompted me to further muse about ways in which this experience of filtered light from above could be replicated within the design of a worship environment. At the time, I was unaware that just such an opportunity would soon arise.

\section{St. Gabriel's Passionist Parish Church: Giving Tangible, Meaningful Expression to Eco-Theology: Dealing with Practical Detail While Maintaining the Vision}

Shortly thereafter, I received an invitation from Father Terry Kristofak, C.P., who at the Chapter had been elected as Provincial leader for a second term, to facilitate a discussion with the Passionist Community of Canada and representatives from St. Gabriel's Passionist Parish. A number of practical circumstances had led to the closing of the Retreat Centre in 1998. Fortunately, however, another opportunity arose that would enable Berry's legacy to continue. At the time, a new rapid transit subway line was being built under Sheppard Avenue in Toronto right in front of St. Gabriel's church. When completed in 2002, it was expected to attract considerable urban intensification along its route. "It was now financially possible to build a new ecologically sound church as well as address the spiritual challenge Berry calls being 'between two stories'” (Dunn 2010, p. 72).

The purpose of the meeting was to envision possibilities for the future development of the property at 650 Sheppard Avenue East, in Toronto. The discussion focused on the following two core values which were to be expressed in the redevelopment:

(1) To determine how the Passionist Community can retain control of a development project that will meet their financial goals and provide senior friendly accommodation for the Passionists living in Toronto.

(2) To determine how to develop a marketable project that will provide a Passionist liturgical statement and a value statement about the natural world as expressed by the Centre for Ecology and Spirituality and vision of Passionist Father, Thomas Berry.

Larkin Architect Limited was subsequently awarded the commission to complete the feasibility study which was launched through the facilitation of a community consultation and visioning workshop.

“St. Gabriel's Sustainable Community Development Design Charette" took place from the evening of 4 December to the evening of 5 December 1998 at St. Gabriel's Seminary as a way of exploring possibilities for achieving these objectives. Participants included vowed members of the Passionist Community, the parish, and a select group of consultants who specialized in sustainable development and affordable housing. This diverse group helped to review a number of important issues surrounding the project vision/dream, governance possibilities, financial goals, current municipal zoning and official plan legislation affecting the property, potential uses on the site, community life of the parish, the built and natural environments, and performance objectives for sustainable development.

A further articulation of the project issues and a written description of four redevelopment options emerged from post-charette meetings with the Passionist Community at St. Gabriel's. A development approximating what was deemed to be most consistent with the values that emerged from the charette was further described graphically in preliminary schematic site plan form to assist in their deliberations. It was hoped that the feasibility study report would now provide the Passionist Community with the data necessary to decide upon an appropriate redevelopment strategy. 
An important outcome of the study was the determination that, due to the nature of its original construction, the existing church would not be easily adaptable to accommodate the anticipated $30 \%$ increase in capacity precipitated by the projected rise in population drawn to live along a major public transit infrastructure. In addition, its central location on the property would limit the potential for redevelopment.

Eventually, by the summer of 2001, in response to a request for proposal, Larkin Architect Limited was successful in being awarded the commission to design the new church. Father Stephen Dunn, C.P. would serve as client contact and champion the project through to completion. The commission would represent a unique opportunity to manifest in physical form, my graduate studies in eco-theology, and to participate in what Thomas Berry described as the "Great Work" (Berry 1999). Eventually, I would come to understand the design process and its ultimate solution as my 'Master's Thesis'. By then, the Passionist Community had come to the decision that they had neither the internal expertise nor the energy to proceed with developing the property on their own. This decision led them into negotiations with a local residential developer. Such arrangements were normally structured to allow for a base purchase price to the vendor that would then incrementally increase with any additional density that the developer could obtain as part of their own approval's process with the city.

Meanwhile, as primary architectural and liturgical consultant, Larkin Architect Limited invited a number of collaborators from various design and engineering disciplines with shared values and expertise in sustainable strategies to join the design team. Working from the values that emerged during the charette with a building committee of Passionist and lay leadership from the parish, we were able to articulate the three foundational criteria that would inform that design process for the new church moving forward:

1. Liturgical design principles as outlined in the Canadian Conference of Catholic Bishop's official document, Our Place of Worship ${ }^{4}$

2. An ecological spirituality based upon the work of Fr. Thomas Berry, C.P. ${ }^{5}$

3. Sustainable design principles as defined by the US and Canadian Green Building

Councils through their LEED (Leadership in Energy and Environmental Design)

Green Building Rating System. ${ }^{6}$

Meeting the first criteria would ensure that the new church reflected current liturgical norms in Canada. Meeting the second criteria, though less tangible, would serve to guide every decision in the iterative design process. We soon realized, however, that one tangible and meaningful way to meet this second criteria would be to have the new church design incorporate leading sustainable design strategies that were emerging within the building industry at the grassroots level in response to what was being identified at the time as the significant contribution to greenhouse emissions emitted by the construction and operation of the built environment. ${ }^{7}$ This goal led to the decision in late 2002 for me to achieve my LEED professional accreditation, a process that would educate and test my knowledge of the US Green Building Council's sustainable design strategies and qualify the project for accreditation. ${ }^{8}$

Although not explicitly identified, I was also aware of bringing to bear on the design process what I had learned from my theological studies about the phenomenological analysis of sacred space while taking a course on Primal Religions taught by professor Carl Starkloff, S.J. at Regis College. Of particular relevance was the seminal work of Harold W. Turner, From Temple to Meeting House, The Phenomenology and Theology of Sacred Space, (Turner 1979) which Fr. Starkloff had graciously leant me from his personal library as a resource for my term paper on the blessing ritual of our firm's recently completed infirmary for the Loretto Sisters in Toronto.

The book defined what was for him the four functions ${ }^{9}$ of a sacred place: (Turner 1979, pp. 19-34)

(1) The sacred place as centre

(2) The sacred place as meeting point between the heavenly and earthly realms 
(3) The sacred place as microcosm of the heavenly realm

(4) The sacred place as immanent-transcendent presence of the divine

\section{How Will You Address the Sun?}

One other critically important input to share at this time was Thomas Berry's response to his community when they asked him how best to embody his ecological spirituality in the design of the proposed new church. Instead of providing an answer to their question, he responded with another question. "How will you address the sun?" The design team interpreted his enigmatic reply as an acknowledgement of the earth's unique relationship to the sun within the solar system and its role in making possible all of planetary life. Although not fully integrated at this moment in the process, the design team knew that "addressing the sun" would become a major design determinant for the new church.

\section{The Iterative Design Process Unfolds}

With all of the preparatory work completed, the design team finally began to articulate the conceptual design for a new church to be located in the southeast corner of the property with frontage directly on Sheppard Avenue for visibility and ease of access not only for those who attended St. Gabriel's from within the parish boundaries, but also for those who came from afar to experience the unique charism of the Passionists, their pastoral leadership, and creative ministries. This scheme was presented to the local municipal planning authorities and immediately rejected because it did not conform to their vision of Sheppard Avenue taking on the character and ambience of Paris's Champs Elysee which was to be articulated by wide, tree lined boulevards, outdoor café terraces providing streetscape animation, and a consistent row of eight storey buildings with colonnaded bases on either side. A single storey worship space and parish centre did not fit within this urban design model. They made it clear to us that a more appropriate location for the church would be the northeast section of the property, set far back from Sheppard Avenue adjacent to Elkhorn Drive, a local neighbourhood residential street.

In the end, a 2-acre site was established for the church to be severed from the original $7 \frac{1}{2}$ acre property leaving a residual parcel of $5 \frac{1}{2}$ acres available for sale to a developer, the proceeds of which would fund the construction of the new church. The original conceptual design that linked the two major programmatic spaces of worship space and parish centre with an enclosed courtyard between, would not work in its new relegated location, so it was back to the drawing boards for the design team (Refer to Figures 1 and 2).

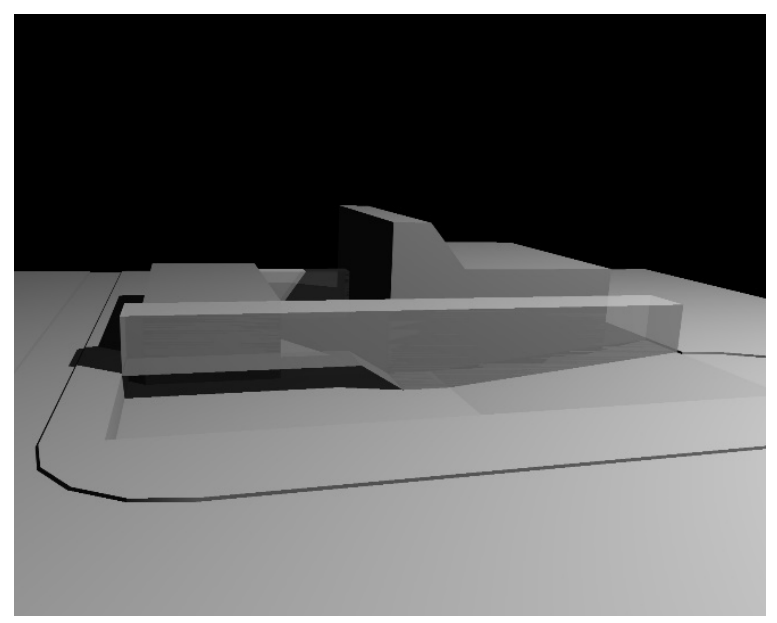

Figure 1. Concept massing model for the first design iteration facing Sheppard Avenue (Credit: Larkin Architect Limited). 


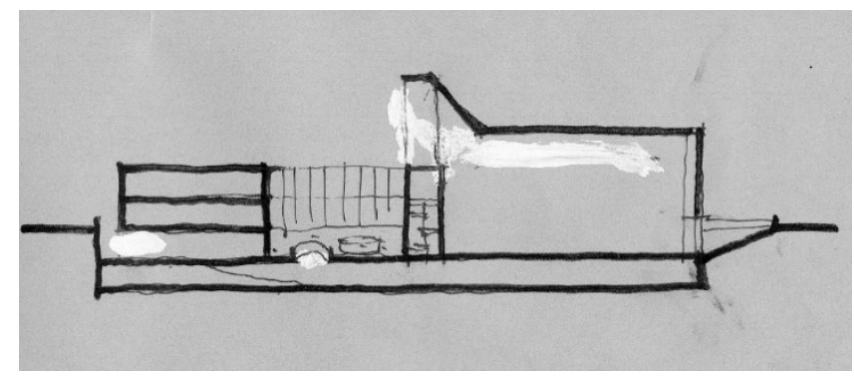

Figure 2. Conceptual Building Section with parish centre on the left and worship space on the right embracing the courtyard (Credit: Larkin Architect Limited).

In the meantime, negotiations with the selected developer had abruptly ended after another, significantly larger, and therefore more lucrative site suddenly became available further to the east on Sheppard Avenue. Without a purchaser, the project could not proceed. After some time had elapsed, one of the parish committee members who also happened to be a local real estate agent, brought another developer to the negotiating table and eventually a purchase price based upon fair market value "as-is" was agreed upon that would enable both parties to continue with their approval's process independently of each other. In other words, the final land valuation was based upon the existing zoning of the property and would no longer be tied to the developer's ability to maximize the density as part of their re-zoning application process.

Because the original 1950s church, still in use by the parish, was located on the portion of land sold to the developer, it would be necessary to first successfully complete the church project's municipal approvals and construction process before the developer could demolish the old church and begin construction on their own redevelopment project. Thus, it was felt that this decision would enable the Passionists and the parish to free themselves from a complex approval's process and expedite the completion of the church. The design of the church was to proceed such that it met all of the current zoning parameters relating to the residual church property and subsequently result in a smooth, as-of-right approvals process.

Unfortunately, this assumption proved to be naïve. The local municipal councilor, in an effort to ingratiate himself with the local residents, had promised them he would object to any redevelopment on the north side ${ }^{10}$ of Sheppard Avenue until the entire south side had been completed, despite the fact that it was in contradiction to the terms already outlined by the city in the context of its redevelopment policies for the Sheppard East Subway Corridor Plan. Furthermore, he insisted on perpetuating the misconception that the land deal between the developer and the Passionists must be tied to maximizing the density on the land, and therefore remained determined to do everything within his power to undermine and stall the as-of-right approvals process for the church. He was convinced that in doing so, the developer would become frustrated with the delays and walk away from the deal, thereby allowing the status quo to remain, and the councilor to appear as a hero to his constituents. His obstreperous machinations were first encountered when the local planning staff was instructed to delay the land severance approval that was necessary to legally distinguish the new 2-acre site for the church from the residual lands sold to the developer. The result of this tactic forced the Passionists to appear before the Ontario Municipal Board which was established to allow parties who had met objections to their municipal approval's process to appeal to the provincial body that oversaw such matters.

A delay of several months did occur, but eventually, the severance was secured and the design team continued their process of attempting to articulate a church that would embody the aforementioned foundational criteria and other important influences established from the outset. With each iteration, new ways of giving expression to them were explored, tested by the design team, and then vetted by the Passionists and the parish building committee. Many practical problems had to be solved in ways that would reinforce rather than undermine the vision quest to embody Thomas Berry's eco-theology. 
Finding creative ways to deal with the parking requirements and other parameters such as building height, setbacks from property lines, etc. imposed by the zoning by-law, mitigating the impact of the developer's surrounding residential towers, determining the best ways to passively harness the sun's energy, managing the relationship between interior and exterior, determining the most appropriate landscaping for the property, the question of worship space seating arrangements and the sequence of movement to the sanctuary in addition to the parameters associated with the project's functional program and budget were just some of the many design considerations that had to be resolved in a coherent, integrated way.

Addressing two significant practical issues which were initially understood to be relatively independent of each other ended up resulting in synergistically contributing to a common resolution while happily strengthening the overall design intent of the entire church. In the penultimate iteration ${ }^{11}$, the worship space was characterized by a flexible circular seating arrangement focused around a central altar that was bathed with natural light via a large sky-lit oculus directly above. This design responded to a desire to highlight the liturgical centre with "heavenly light" thereby serving to distinguish this space for clergy from the congregational seating and giving expression to Turners' function of providing a meeting point for the heavenly and earthly realms. At the south end of the worship space was a massive stone wall thick enough to have carved out of its massive form spaces for the reservation of the tabernacle, the reconciliation rooms, and carefully framed openings that provided views and access to full height, wall to wall, south facing glazing and the garden beyond. The winter sun's energy would be passively harnessed through the south glazing which would then be stored in the mass of the "trombe" wall ${ }^{12}$ of stone as a heat sink during the day and then release that energy into the space at night, thereby reducing the dependency on fossil fuels to heat the building (Refer to Figure 3). The garden, which was in fact a "green roof" above the parking lot, had its landscaped supporting concrete slab "folded" up about 20 feet in the air in order to provide an opening for natural light to find its way to the parking garage below and artificially extend the horizon of the garden to "mask" the surrounding residential towers.

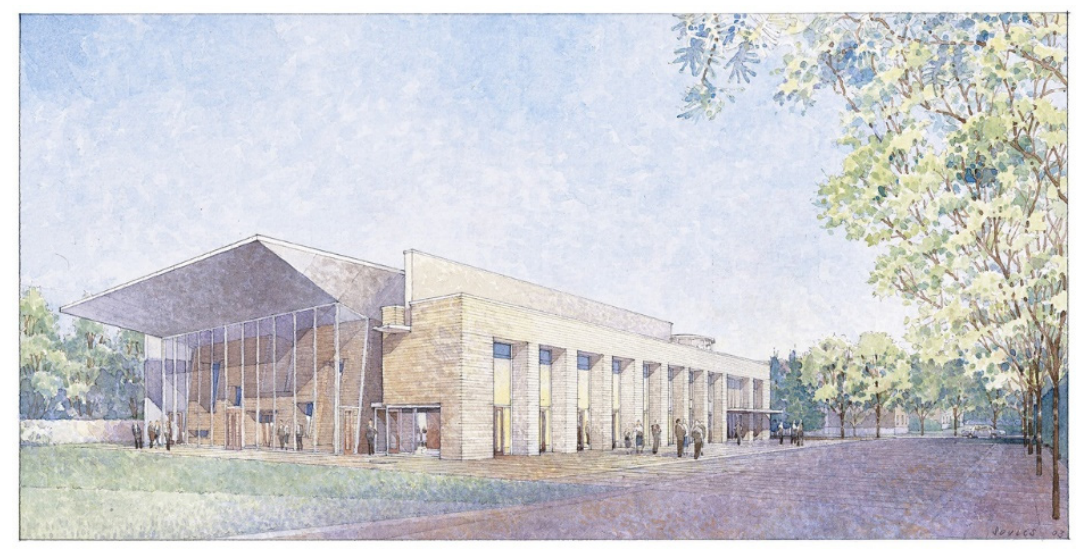

Figure 3. A water colour rendering of the iterative scheme incorporating a "trombe" wall (Credit: Jon Soules).

Just after presenting that scheme, some members of the parish building committee visited the Passionist Retreat Centre in West Hartford, Connecticut and came back impressed with the antiphonal seating arrangement they experienced while attending mass. Typical of monastic traditions, this form of seating is characterized by two banks of pews or stalls that face each other to facilitate the call and response of Gregorian chant and the "praying of the office". The committee thought that this arrangement would be a way in which they could honor the monastic tradition of the Passionist charism. ${ }^{13}$ From the perspective of the Constitution on the Liturgy of Vatican II and the Roman Missal, this seating arrangement, like the previous circular one, also satisfied the preference that the parishioners be aware 
of each other, gathered as a faith community to share in the sacraments, representing a primary symbol of Christ's presence in their midst. This desire cited by the committee also prompted Father Steve Dunn to suggest eliminating the "trombe" wall altogether which would then open up an expansive view to the garden and thereby serve to extend the sacred space of the worship environment into the sacred space of the garden beyond to emphasize that when we gather to worship, we do so within the greater context of creation.

This prompted salvaging of the original church pews, re-finished and modified to suit the new arrangement, and initiated a relocation of the reservation chapel and the reconciliation rooms to the north end of the worship space. This allowed the concrete floor and flanking walls of the south facing window to serve as the heat sink now that they were exposed to the winter sun's rays. Fabricated to be eight times more energy efficient than the walls of the original church, the expansive glass of the south window, in addition to offering a visual connection with the garden, also helped to improve the energy efficiency of the new church. The precise form and extent of the projecting roof canopy ensured the maximum potential for harvesting passive solar heating in winter while shading the building to reduce cooling loads in summer (Refer to Figure 4).

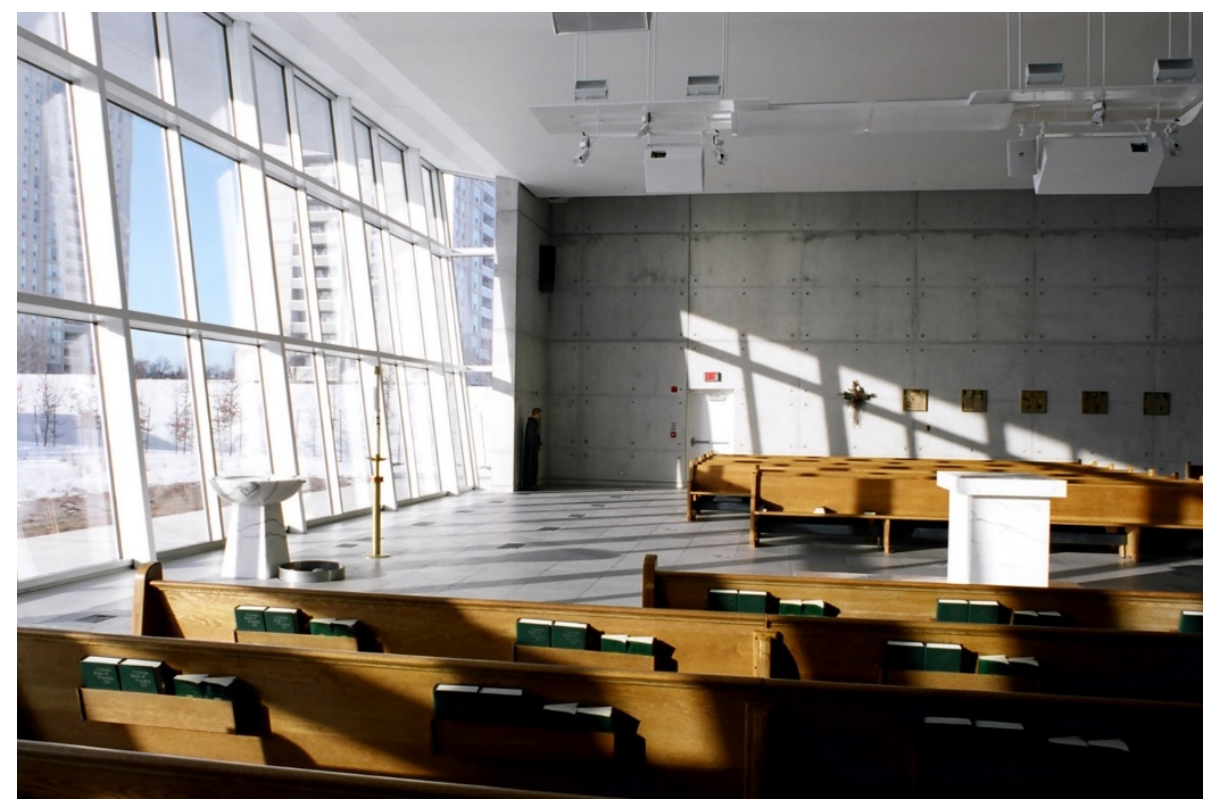

Figure 4. A view of the nave in January demonstrating passive harvesting of the winter sun's energy. (Credit: Steven Evans).

The antiphonal seating arrangement also allowed for the articulation of a sacred axis that began with the presence of Christ in the consecrated eucharist reserved in the tabernacle at the north end of the worship space and terminated with an understanding of the immanent presence of the divine in creation as expressed by the garden at the opposite end (Refer to Figure 5). This sacred axis would also embrace the placement of the altar, the ambo (pulpit), and the baptismal font all of which were reclaimed from the old church and modified to alert parishioners that the new church design both honoured the long tradition of Passionist leadership and also spoke of "the New Story". Sufficient space was left between the altar and ambo to emphasize that receiving the Word of God would invite worshipers to participate in the eucharistic meal. The presiding priest's chair would be located at the centre point between the altar and ambo in order to recognize his leadership role and symbolic representation of Christ's presence. However, instead of being elevated, it would remain level with the congregation, to emphasize that the entire assembled community of faith, by virtue of their baptismal covenant, formed part of the royal priesthood. Finally, the original marble font, re-designed to flow with "living water" and reference the assembly of roof scupper and wetland, which according to contemporary 
liturgical norms is most often located near the entrance to the worship space, was uniquely placed immediately in front of the window overlooking the garden to emphasize that when we are baptized into the Christian faith community, we are also welcomed into the broader Earth community (Refer to Figure 6).

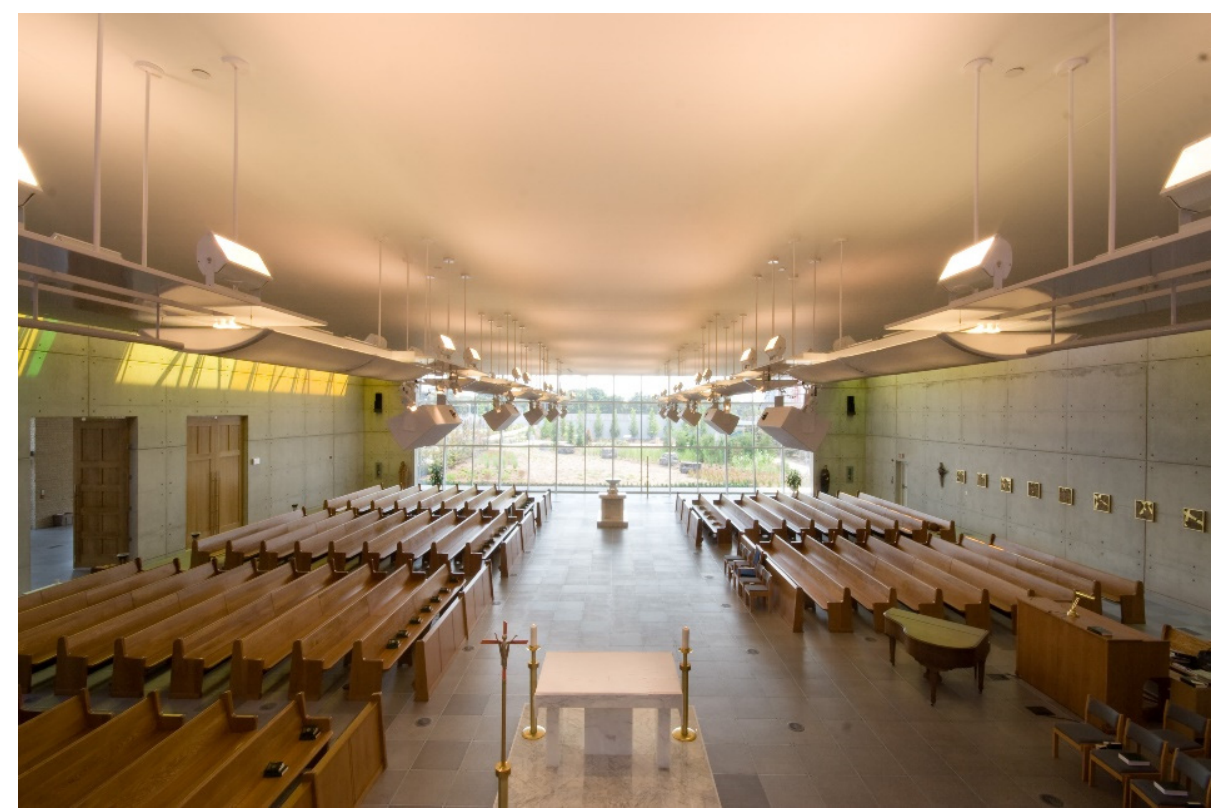

Figure 5. A view along the sacred axis towards the garden (Credit: Martin Knowles).

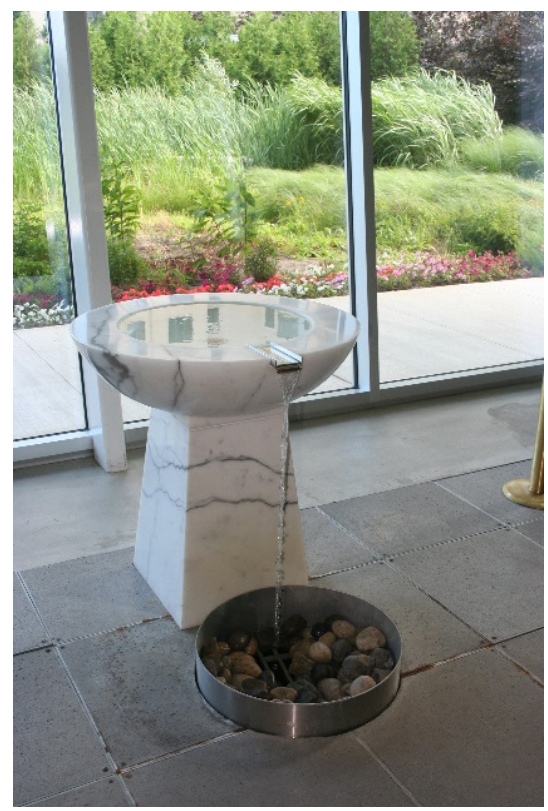

Figure 6. Baptismal font placed in front of the window overlooking the garden (Credit: Roberto Chiotti).

Serendipitously, during this time of design development, our landscape architect, Ian Gray, introduced us to David Pearl, a glass artist friend, who collaborated with the team to create coloured glass panels for integration into the perimeter skylights that were situated above the remaining three walls of exposed concrete. The skylights were envisaged as a way of interpreting the formative experience that I had encountered on the forested valley floor during the Passionist Chapter in the Poconos. Movement from the south to the north is reinforced by the arrangement of colours in the skylight. Brilliant yellows are situated 
closest to the sun's intense light at the south end whereas the deeper, richly hued azure blues and crimson reds at the north end provide a beautifully mysterious and meditative light for the chapel of reservation and the adjacent reconciliation rooms. The ceiling of the worship space stops short of the walls on all sides, appearing to hover weightlessly over the congregation, the cosmic coloured light of the perimeter skylights spilling into their midst from an unseen source high above. The dynamic play of natural light that is filtered by Pearl's brilliantly choreographed coloured glass panels and further fractured by wall-mounted dichroic coated reflectors gives the worshipping faith community a sense that the cosmos is embracing the liturgical environment and actively participating in the ritual action of the liturgy. Similarly, time also takes on a cosmic dimension as the colours move in sync with the earth's rotation. Seasonal influences on the sun's intensity and inclination, together with the daily diversity of weather conditions, ensure that no two masses will experience an identical liturgical environment (Refer to Figures 7-10).

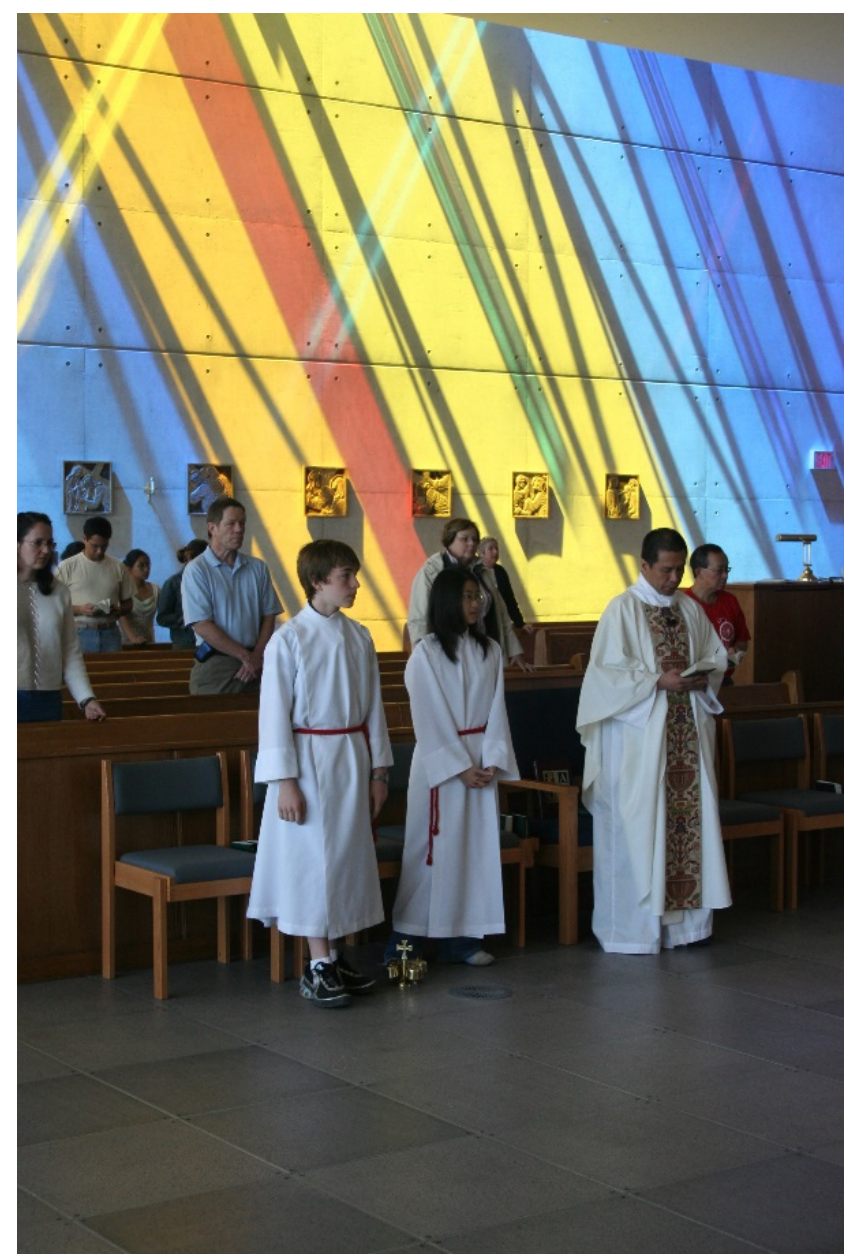

Figure 7. View of the worship space west wall at the beginning of the 12:30 p.m. mass (Credit: Roberto Chiotti). 


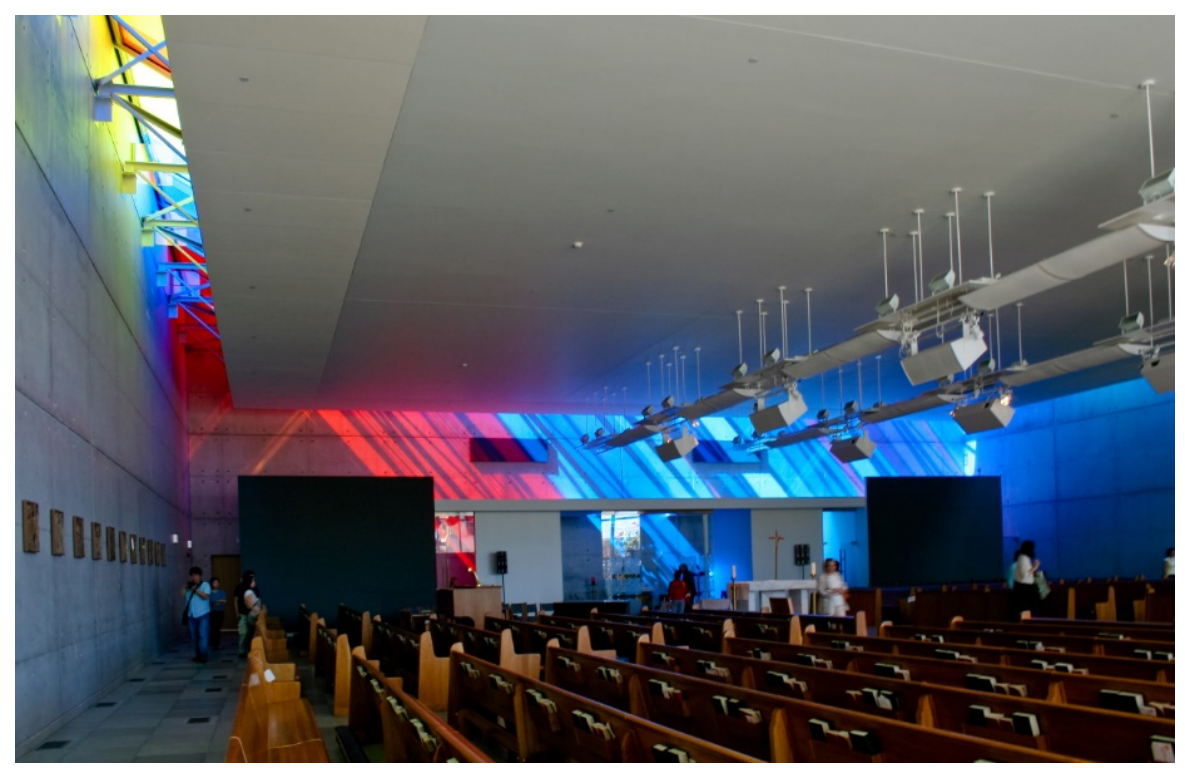

Figure 8. View of worship space north wall during late afternoon (Credit: Scott Norsworthy).

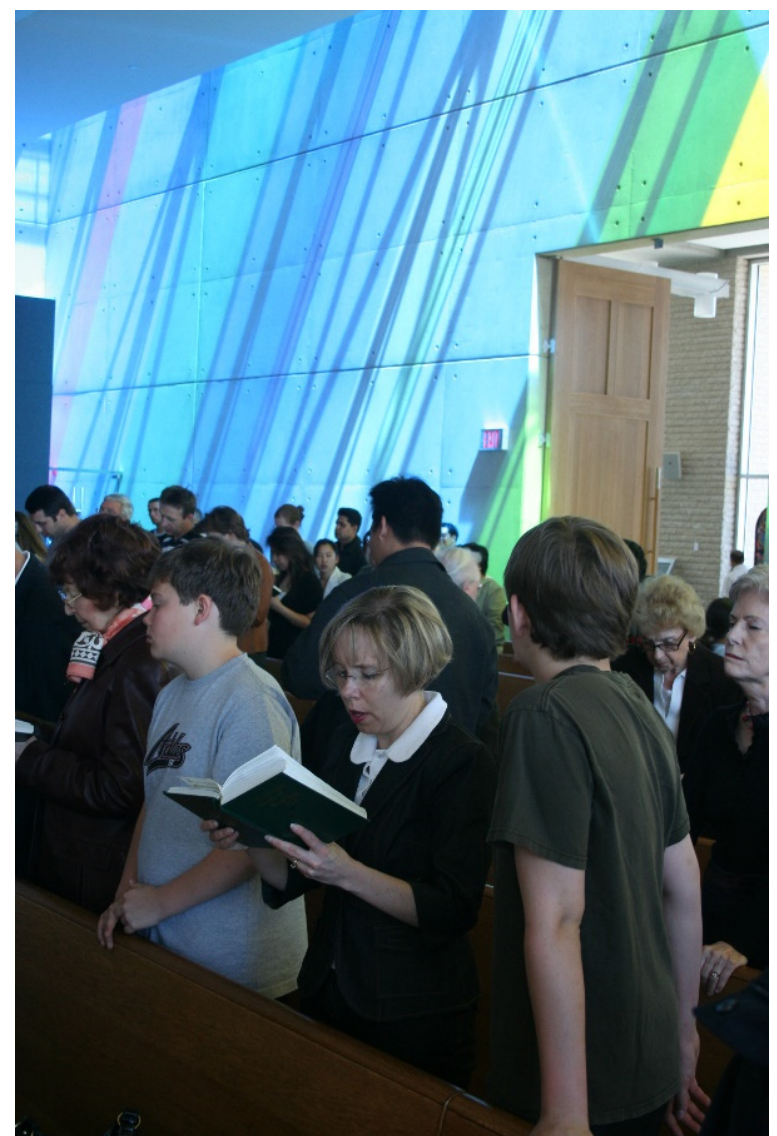

Figure 9. View of the worship space east wall at the end of the same 12:30 p.m. mass (Credit: Roberto Chiotti). 


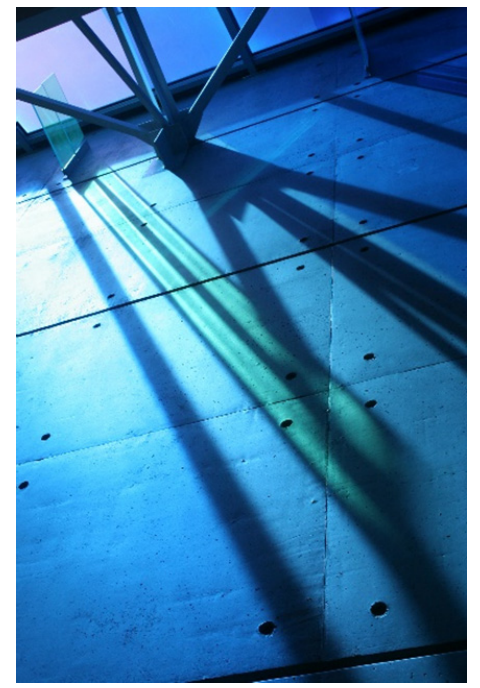

Figure 10. Close up of skylight with view to dichroic lens mounted on wall (Credit: Scott Norsworthy).

The nave is entered from the narthex on the cross-axis through a pair of massive fifteen-foot-high paneled doors reminding us that Christ is our "gateway" to salvation. This central ceremonial aisle ends at the sacred axis, facing the presider's chair, which is located in the front row of pews amongst the gathered worshipping community. The space at the crossing remains void, free to receive the gifts, the bride and groom, and the body of the deceased. It also serves as a place to identify the liturgical season, allowing the altar to remain unfettered as a primary symbol (Refer to Figure 11).

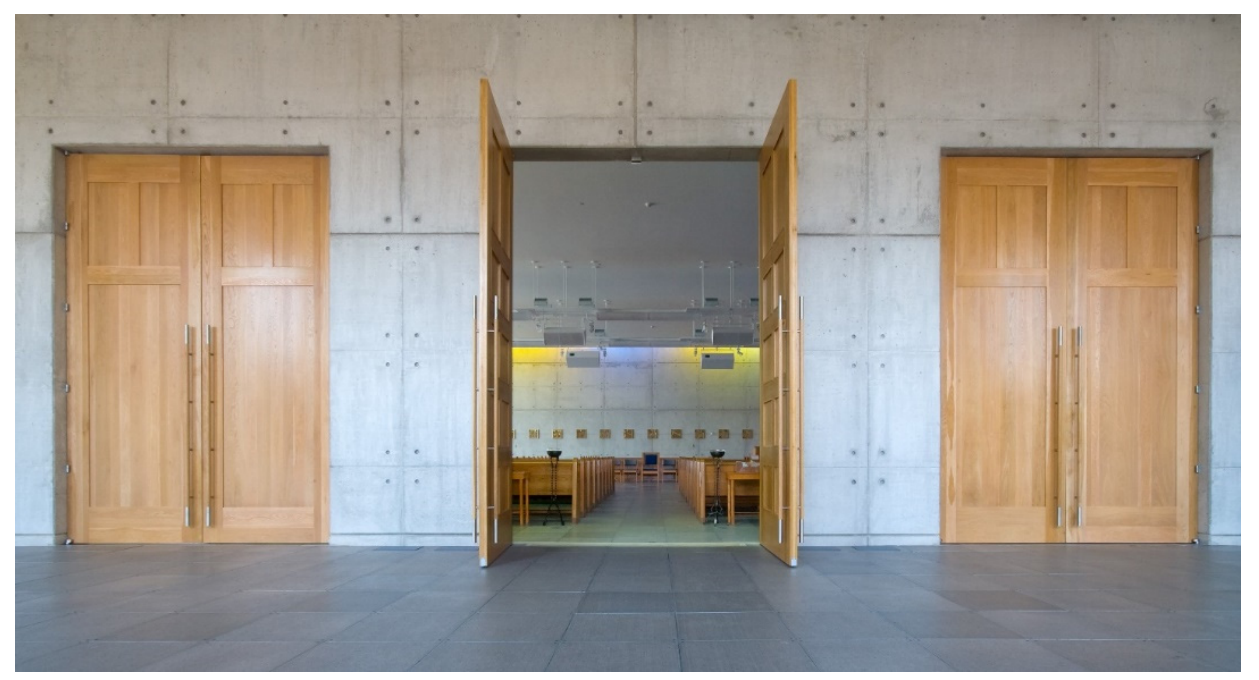

Figure 11. Main doors from the narthex to the worship space along ceremonial axis terminating with the presider's chair (Credit: Steven Evans).

Further sketching and design development eventually resulted in a scheme that was agreed upon by the Passionists and the committee to be ready for the process of obtaining site plan approval with the city. ${ }^{14}$ Working closely with the urban planners and legal advisors retained by the Passionists, the design team was instructed to submit a scheme that met all of the city's zoning requirements without having to seek variances in an attempt to streamline the approval's process and expedite the construction of the new church. Notwithstanding, the chief planner had the intention of using the private church property to extract a public pedestrian thoroughfare linking Sheppard Avenue (now to the south of the church property) with Elkhorn Drive, bordering on the church's north end of the property. Not only was planning approval contingent upon providing the thoroughfare, 
but it had to be done in a manner acceptable to the planning authority, which in this case, dictated a straight pathway from one end of the site to the other.

This mandate was in direct contradiction to our design for pedestrian movement which was carefully choreographed to prepare parishioners for worship services. The path did begin with a straight section that led from the south property boundary to a circular terrace located on the south edge of the main garden, but deviated thereafter. Pedestrians who approach the church from Sheppard Avenue were greeted with "stations of the cosmic earth" situated strategically along the path through the garden. Based upon the series of eight stained glass windows commissioned for the chapel at the Passionist's Holy Cross Centre for Ecology and Spirituality, the stations depict significant transformational moments in the evolutionary story of the universe and the pilgrim journey of humankind within that story. The first station depicts the "big bang", the initial bursting forth of energy at the beginning of time from which all else has evolved. The following two stations move through the coalescing of matter to form our solar system and the emergence of early life forms within the seething primordial broth of our planet's oceans. The fourth depicts the emergence of the human. Another station, which is not part of the sequence, depicts the cross lying flat on the earth surrounded by flowers as seen from above to remind us that the story of the cross is linked to the story of creation. A void with flowers emerging exists where the arms of the cross intersect reminding us that even though it is a symbol of suffering and death, the cross also proclaims hope and resurrection. It can be viewed from a circular terrace that terminates the walkway from Sheppard Avenue (Refer to Figure 12).

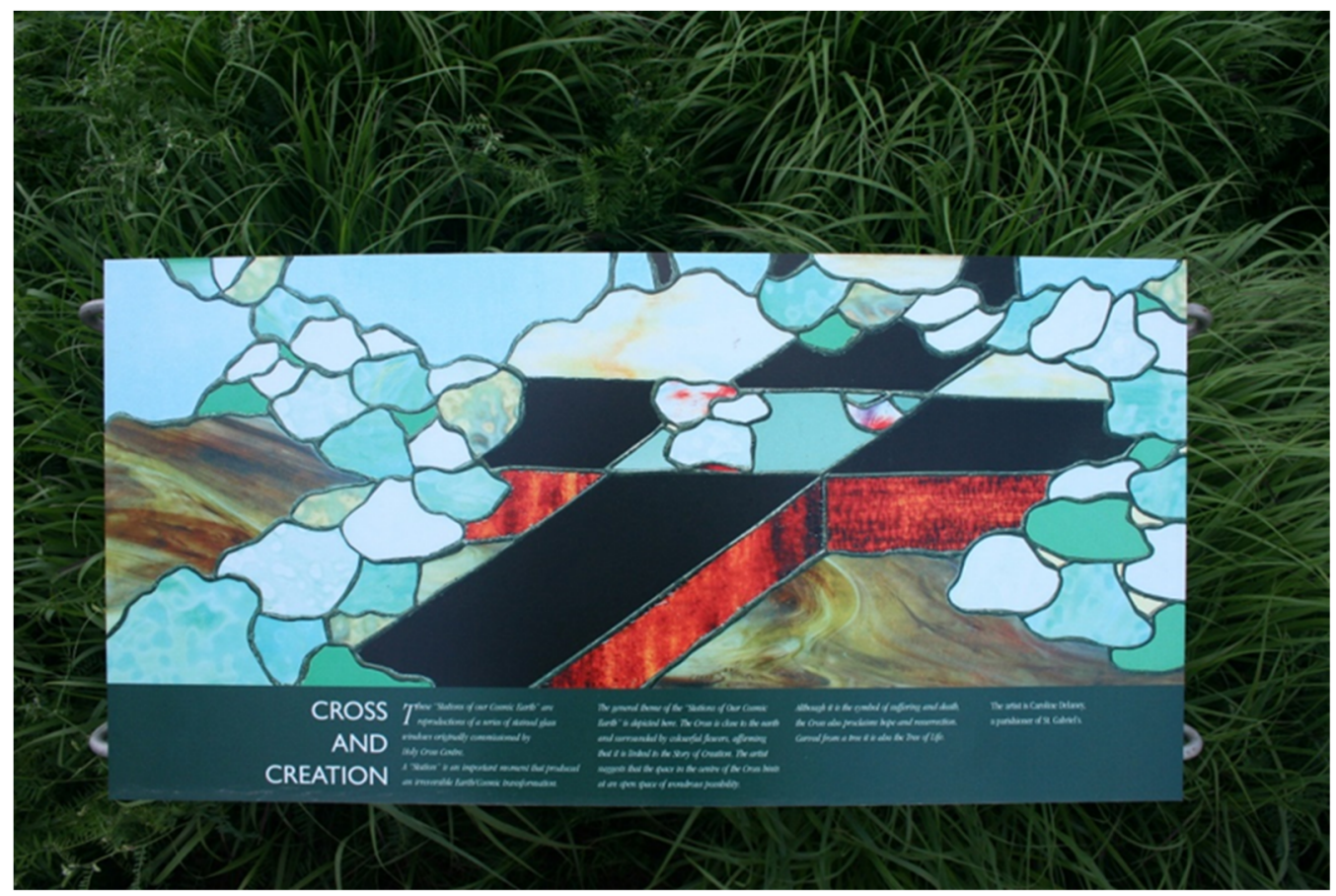

Figure 12. The station (which is not part of the sequence) depicting the cross. Each station has a written description of the image with accompanying mediation (Photo Credit: Roberto Chiotti).

From the central vantage point of the circle, those approaching from Sheppard are invited to pause and reflect upon several symbolic representations of Christian theology integrated into the design of the church that were designed to initiate a shift in one's orientation towards Berry's eco-theology and his understanding of the Earth as the primary revelatory presence of the divine. First and foremost, the circle would afford an expansive viewpoint to take in the beauty of the garden designed to reflect an indigenous, pre-settler landscape. Visually aligned with the circle's centre, directly to the north, can be seen a sculpted roof scupper which, like the gargoyles of Gothic cathedrals, is designed to direct rainwater from the building, (and in this case), into a constructed wetland below. A primary 
element employed in the Christian initiation ritual of baptism to symbolize new life in Christ, the intention was to demonstrate that water had to be conserved, protected, and remain unpolluted lest it come to represent death instead. Whenever it rained, the wetland plants would flourish, but during times of drought, they would wither, thus reiterating the preciousness of water as a natural resource (refer to Figure 13).

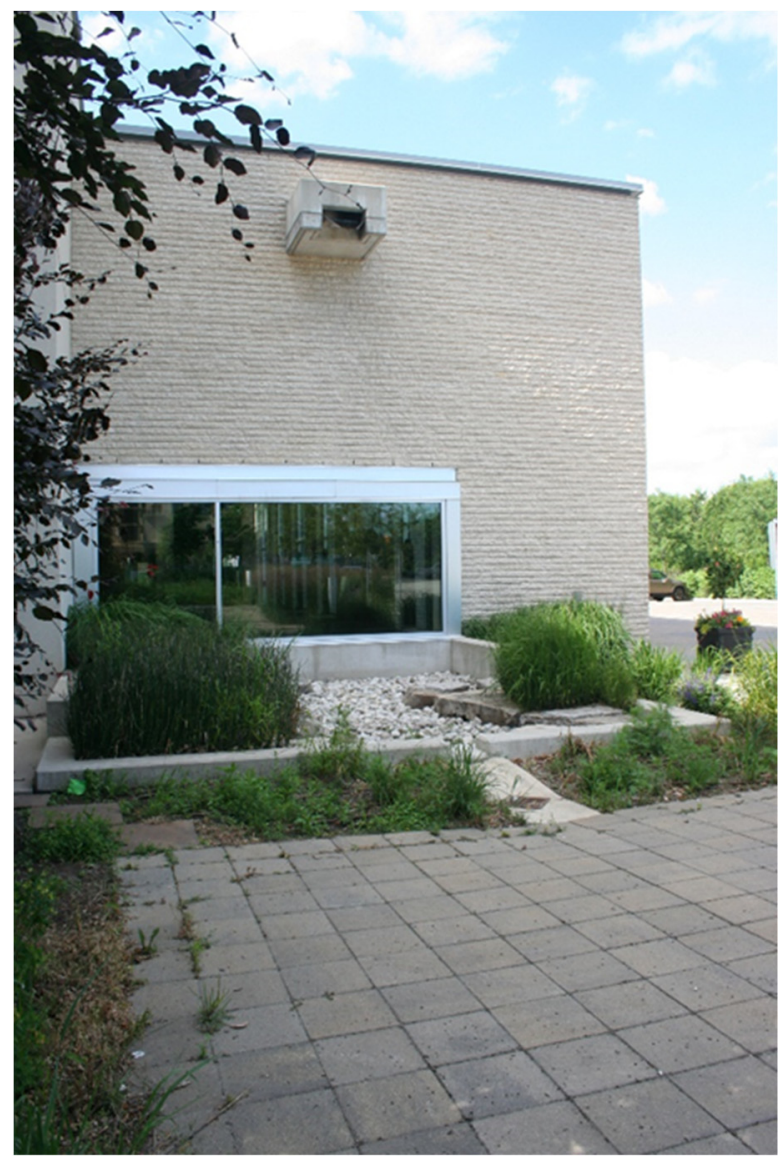

Figure 13. A view of the roof scupper and wetland (Credit: Roberto Chiotti).

Juxtaposed to the "cross" station and the circle terrace are the remains of a tree that has been reclaimed from the property, its form "resembling a bowed head with branches splayed outward like suffering arms" (Rochon 2006, p. R4). The copper cross from atop the original church roof is mounted to the back of this tree, reflecting a contemporary understanding of the Passion of Christ including the Passion of the Earth. To continue their approach towards the church, visitors must first re-orient their direction to circumnavigate a portion of the circle before continuing their journey under the outstretched arms of the natural "tree cross". A straight path would therefore undermine this consideration (Refer to Figure 14).

Upon passing the constructed wetland, parishioners emerge upon a generously proportioned piazza designed to be used as a seasonal outdoor gathering space and staging area for weddings and funerals. The deeply recessed arcade that articulates the front wall of the narthex overlooking the piazza is a contemporary expression of the form and architectural detailing of the Passionist Motherhouse in Rome. Made of a unique limestone from Manitoba that is distinguished by its many 450-million-year-old (Late Ordovician) embedded fossils of ancient sea crustaceans, ${ }^{15}$ the fabric of the narthex defines an important chapter in the geological history of Canada and reminds us that the 2000-year Christian story is part of the earth's 4.5-billion-year story (Refer to Figure 15). 


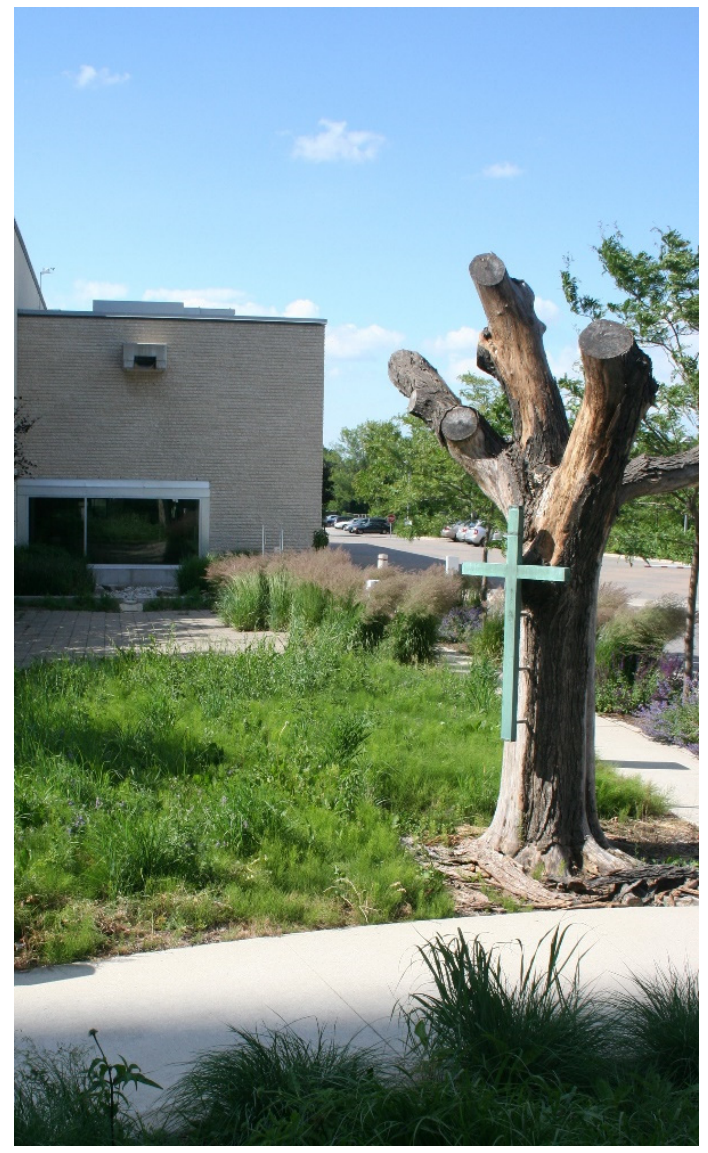

Figure 14. A view of the "natural cross" (Credit: Roberto Chiotti).

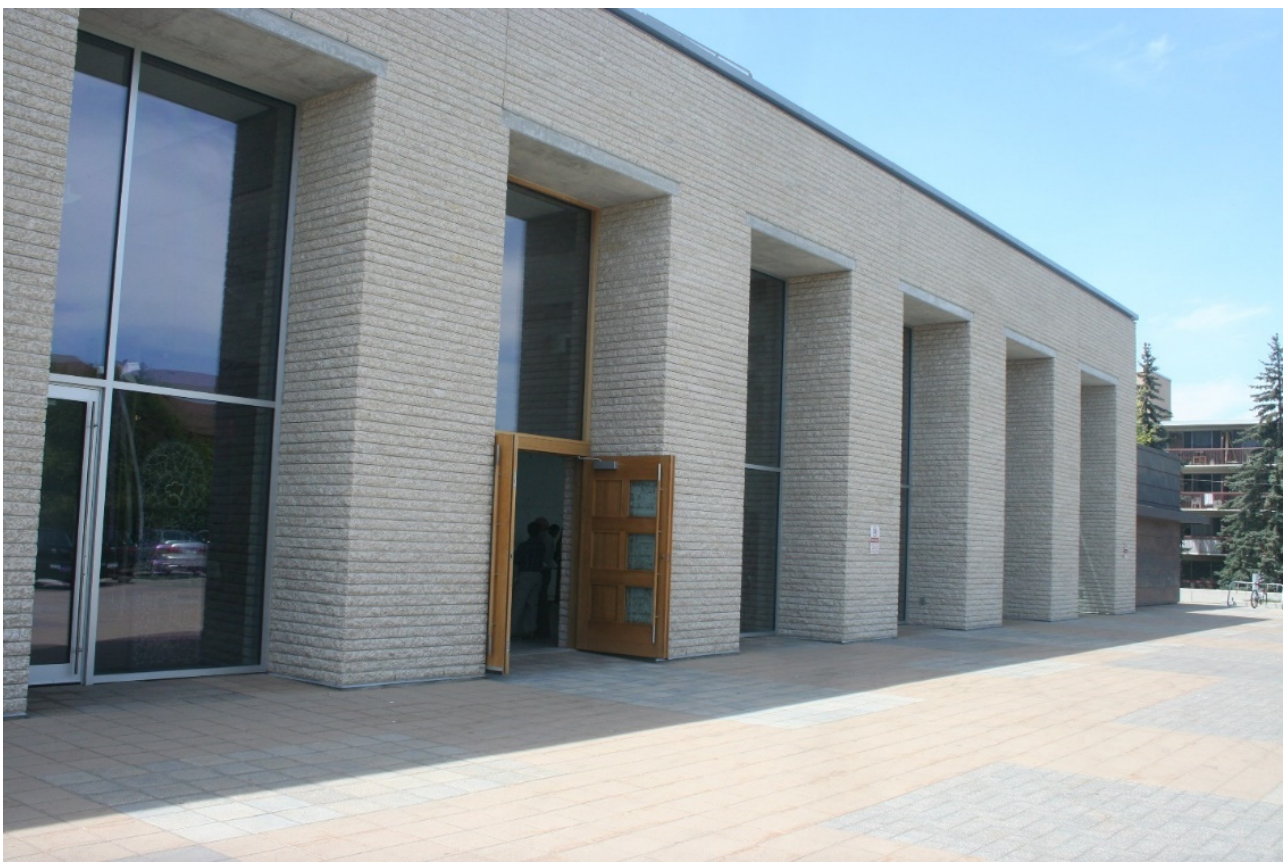

Figure 15. View of the ceremonial entrance to the narthex from the piazza showing the Tyndall Stone cladding high-lighting 6 of the 7 deep set arches referencing the Passionist motherhouse in Rome (Credit: Roberto Chiotti). 
Once inside, the narthex ${ }^{16}$ is terminated at the north end by a sky-lit, "living wall" (Refer to Figure 16). Water running over the roots of the living wall's plant material conditions and purifies the air of the narthex and worship space. The enzymes in the roots of the tropical plants process the volatile organic compounds and other atmospheric pollutants to "freshen" the air while the water provides natural humidification during winter and de-humidification in summer. Parishioners emerging from the underground garage are drawn into the narthex light above by the "living wall" and as they pass it are reminded of their baptismal covenant by the sound of its purifying waters (Refer to Figures 17 and 18). They are also reminded of how the rainforests serve a crucial role as the earth's lungs. At the opposite end of the narthex is a window that frames a view of the wetland and "tree cross" beyond.

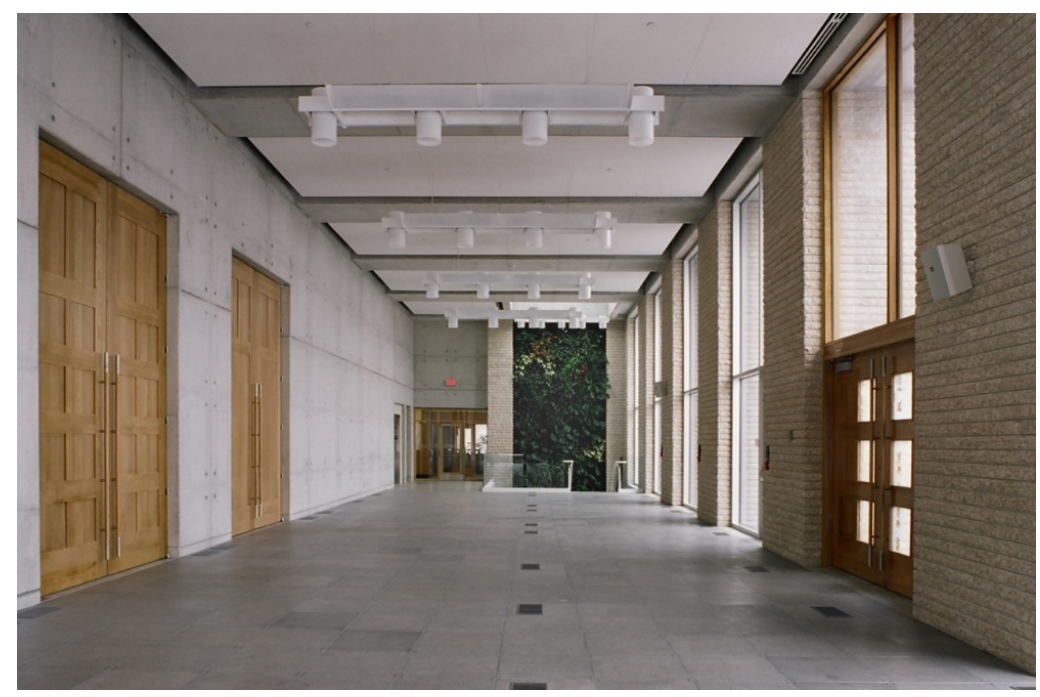

Figure 16. View of the narthex looking towards the "living wall" at the north end (Credit: Steven Evans).

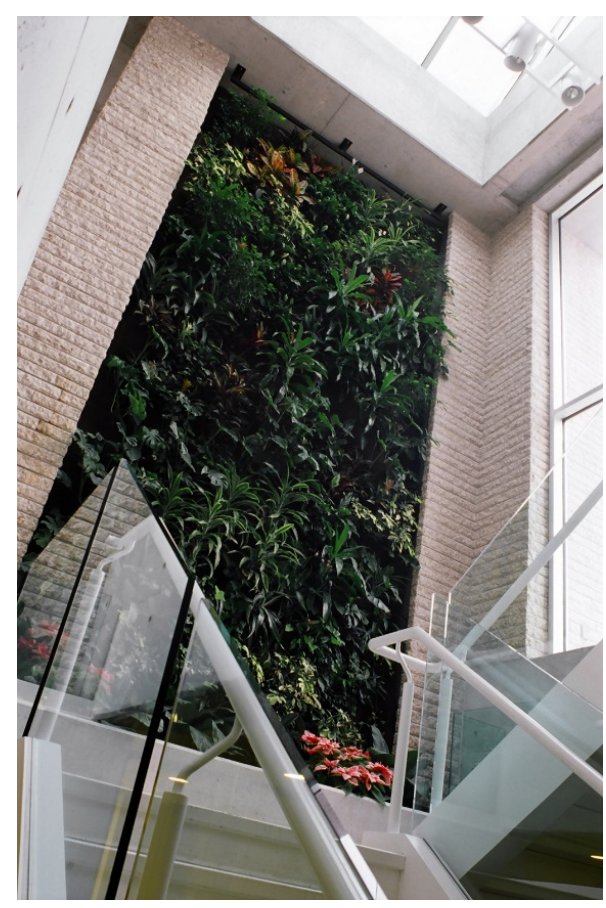

Figure 17. View of "living wall" as one ascends from the underground parking lot (Credit: Steven Evans). 


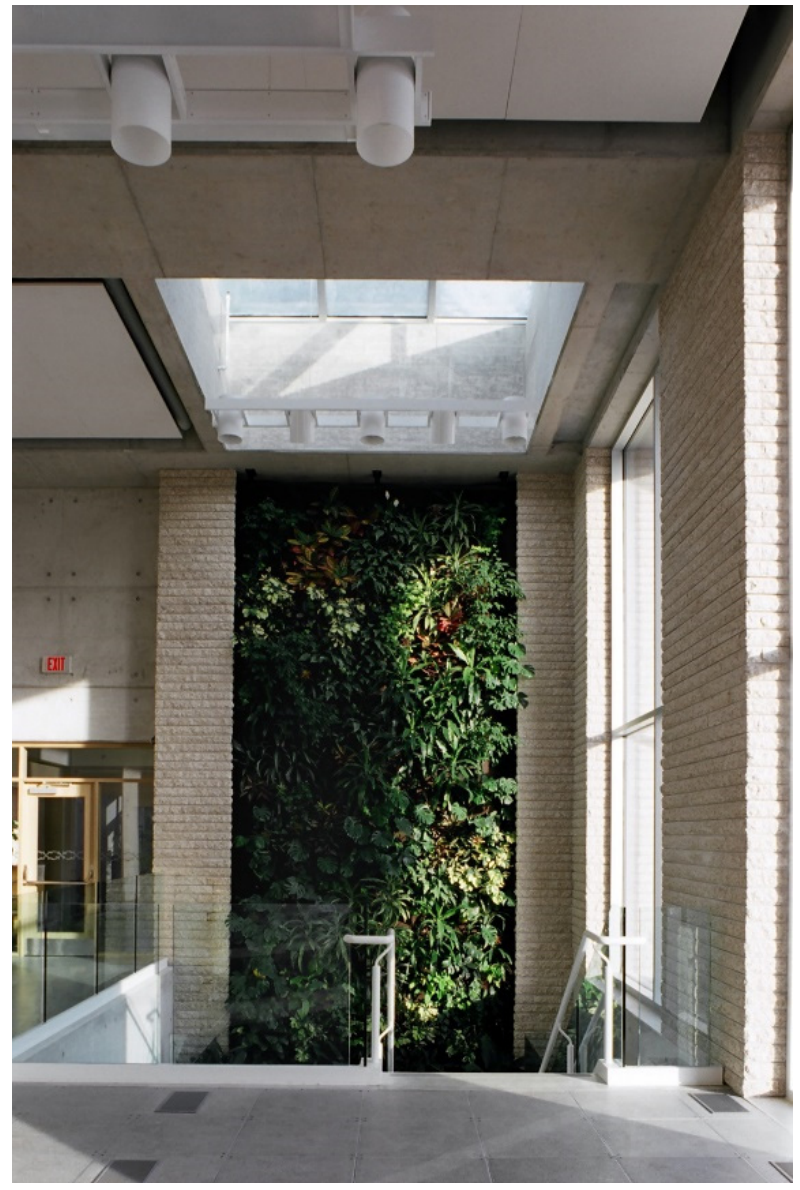

Figure 18. A close-up view of "living wall" from the narthex (Credit: Steven Evans).

Alternatively, one can delay proceeding from the circle terrace point of orientation and can rather choose to journey deeper into the garden passed the remaining stations. If so, they first come upon the fifth station which depicts the beginnings of agriculture, responsible for the significant shift away from nomadic hunting and gathering towards settlement and a more pervasive human presence upon the earth. The station characterizes this change with the appearance of a deep fissure that both physically and symbolically identifies the emerging rift between humans and the rest of creation (Refer to Figure 19). In the next station, this fissure increases in breadth and depth to reflect the emergence of religions. Here the tree reappears, within its trunk and branches, the image of two human figures intertwined, one revealing an expression of suffering, and the other ... an expression of ecstasy. The seventh station depicts the appearance of technology with the prophetic image of an atomic bomb's mushroom cloud overshadowing the earth's fertile green landscape below. The final station is out of sequence and is meant to represent a hopeful, resurrection theme. Captured in a large mural made from colourful Murano glass tile mosaics salvaged from the front face of the original church, it describes in abstract form, the bursting forth of flowers that characterized the dawn of the Cenzoic Age of earth history after the extinction of the dinosaurs some sixty-five million years ago. The angiosperms enabled the diversity of plant and animal life to evolve and flourish when humans appeared as a distinct species. 


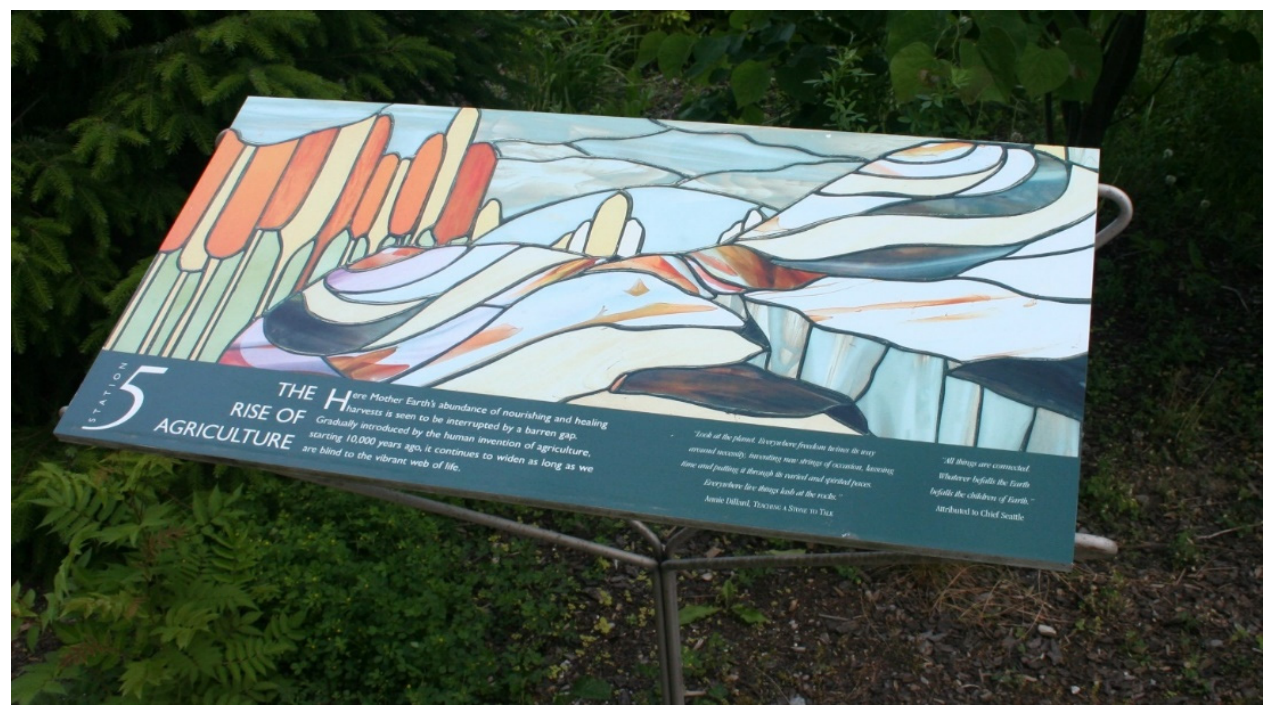

Figure 19. View of the 5th Station of the cosmic earth depicting the rise of agriculture.

The impasse that existed between the chief city planner's desires and the choreographed sequence of movement envisioned by our design prompted another appeal to the Ontario Municipal Board which ultimately sided with the church in its decision citing religious interpretation as a legitimate design determinant. With this decision, all municipal approvals were now theoretically secured and the execution of the site plan agreement with the city should have proceeded in a timely manner. However, once again, the local councilor used his influence to delay the process which ultimately required yet another appeal to the Ontario Municipal Board. The councilor finally relinquished his interference, but not without imposing a further caveat enshrined by the site plan agreement that forbade having any projections beyond the parapet of the church roof. Essentially, this stipulation prevented the possibility of installing solar photo-voltaic panels on the roof, at least for the foreseeable future.

Meanwhile, the delays coincided with inflationary pressures precipitated by the construction of venues to host the Olympic Games in Beijing, China, resulting in volatile market conditions that saw up to 50\% increases in the price of steel, copper, and concrete. Final cost estimates for the church were escalating beyond the Passionists financial resources designated for the project. Once again, the design team had to return to the drawing table to conduct what is known in our industry as "value-engineering", a term used to describe design changes, a.k.a. cuts and reductions, required to reduce costs to the point at which the project could be completed within budget. The design team's response was to create a spreadsheet of items to be sacrificed along with their associated costs, much like an a-la-carte dinner menu, to assist the Passionists in making some difficult decisions. Items that ended up being deleted included the entire second floor of the administration wing meant to serve as a Passionist research centre and archive with its double helix access stair, the proposed green roof above the worship space, the buried garden cisterns that would store rain water harvested from the narthex roof for irrigation, and the heat chimney and operable windows that would allow for naturally occurring displacement ventilation in the church (Refer to Figure 20). 


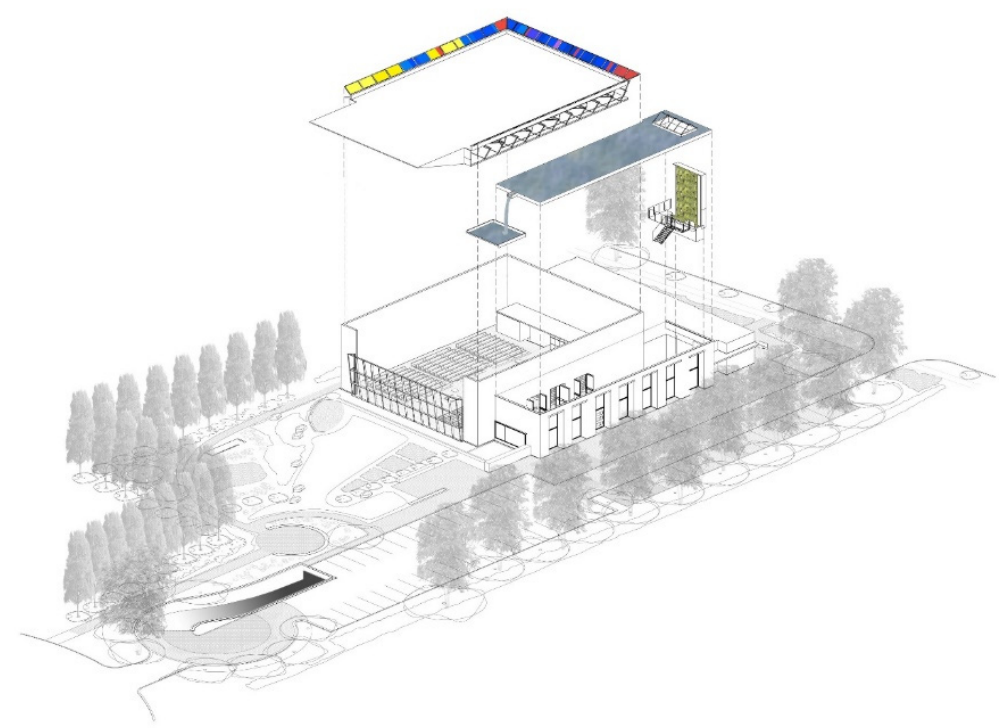

Figure 20. An exploded axonometric drawing for the final scheme that was built highlighting the major building features and its relationship to the garden. Entrance to the underground parking is located in the bottom left corner. This unprecedented decision enabled over $50 \%$ of the church site to receive soft landscaping (Credit: Larkin Architect Limited).

\section{Conclusions}

Ultimately, and in spite of the many challenges and setbacks encountered throughout the design process, I believe that the built solution, finally consecrated in November of 2006, responds to current liturgical norms and represents a tangible, meaningful expression of the eco-theology of Thomas Berry, demonstrated by a litany of sustainable design features that significantly reduces the building's ecological footprint while providing a healthier environment for building occupants. ${ }^{17}$ Remaining steadfast at addressing and seamlessly integrating the three core criteria for the design process resulted in the emergence of a new typology for Christian sacred space that engages the senses, demands reflection, and invites transformation. And although the new church design did result in some parishioner attrition for those more comfortable with traditional worship environments, ${ }^{18}$ many chose to remain, and others, well beyond the parish boundaries were inspired to come. From the very beginning, the Elliot Allen Institute has held a monthly "eco-sabbath" at the church and I continue to provide tours several times a year for students of all ages and educators across many disciplines. The vision of the church as transcendent sacred space and its role in the community have evolved with the lived experience of its parishioners. New leaderships and ministries have emerged over the years like the "garden ministry" which has re-designed some of the original landscape on the property employing Hugelkulture ${ }^{19}$ methods to sustainably grow organic fruits and vegetables for local shelters and to attract pollinators (Refer to Figures 21 and 22). I recently attended a garden retreat hosted by the Garden Ministry and while getting my hands dirty, digging in the rich soil, I became re-enchanted with the flora and fauna found on the property. As a parishioner and member of the "Building Management Committee", I have also come to intimately know every corner of the building and have had the privilege to watch it gradually and gracefully take on the patina of age. It is a rare opportunity for an architect to enjoy such continuing access to the buildings they design, and for that I am eternally grateful to the Passionists and the St. Gabriel's parish community. 


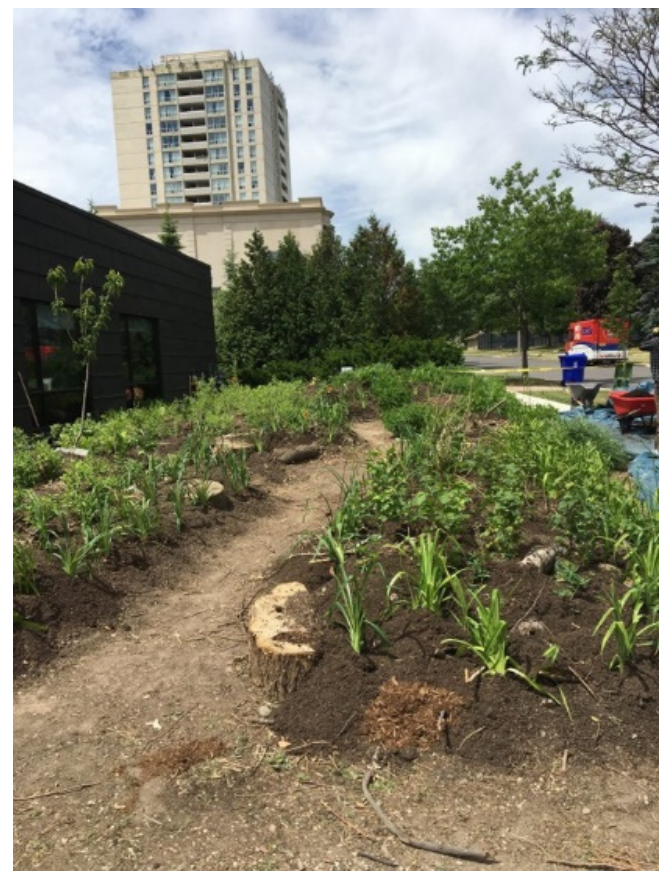

Figure 21. A view of the north garden being re-planted using 'Hugelkulture' to grow fruits and vegetables (Credit: St. Gabriel's parish).

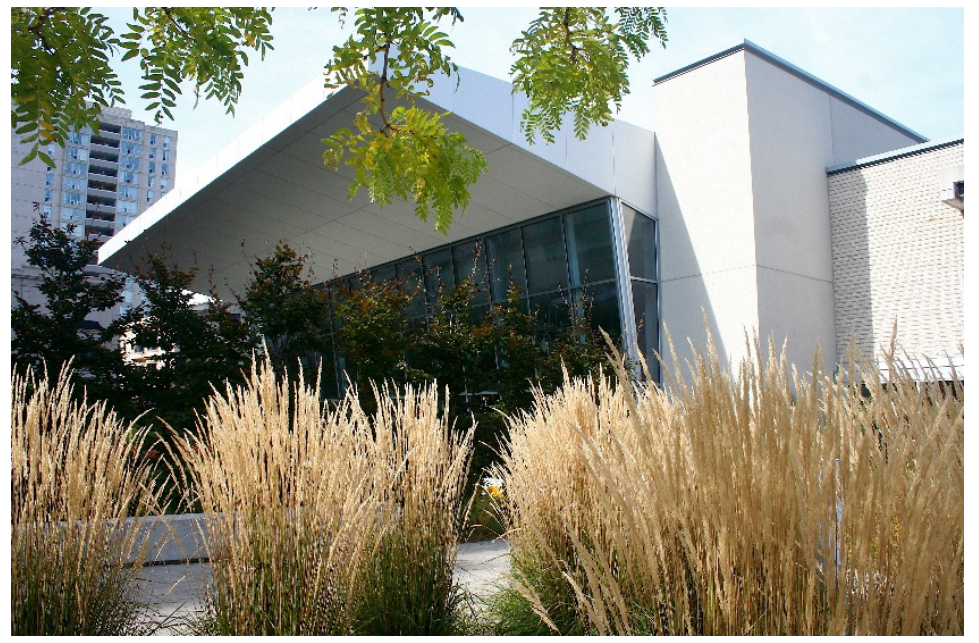

Figure 22. A view towards the iconic projecting roof canopy passed the wild grasses and beech hedge meant to reflect pre-settlement landscapes (Credit: Roberto Chiotti).

Funding: This research received no external funding.

Institutional Review Board Statement: Not applicable.

Informed Consent Statement: Not applicable.

Conflicts of Interest: The author declares no conflict of interest.

\section{Notes}

https:/ / en.wikipedia.org/wiki/Gulf_War (accessed on 1 December 2021).

As a way of enhancing the understanding and appreciation for the unique charism of the Passionists, the leadership held a series of retreats for those lay persons involved with Passionist parishes and ministries that they named "Mission Fulfillment".

3 It is the tradition of religious communities to convene a 'Chapter' every four years, held over several days to review their mission, plan their ministries, and elect the leadership for the next term. 
$4 \quad$ First and foremost, it was important that the space designed to celebrate mass and other rites of our Catholic faith reflected current liturgical norms. We used as our source, the official document, Our Place of Worship, issued in 1999, by the Canadian Conference of Catholic Bishops. In the words of His Grace, Archbishop Marcel Gervais, Chairman of the Episcopal Commission for Liturgy, "It ... offers principles and characteristics of an appropriate place, always with the primacy of the assembly in mind, and it outlines the requirements of the liturgy according to the Constitution on the Liturgy of Vatican II and the Introduction to the Roman Missal".

5 Berry was never prescriptive about how each profession was meant to bring about a mutually enhancing, human earth relationship. Instead, he provided inspirational references to exemplars and invited us all to re-invent our professions in ways that would allow us to participate in what he identified as "The Great Work" of humanity in these times. Refer to his book by the same title for further reading.

6 The US Green Building Council and its LEED rating system were established by leaders within the building industry to quantify sustainable design metrics for buildings and offer third party certification. From the outset, we agreed upon a target of achieving LEED Silver Certification for the St. Gabriel's project but ultimately achieved LEED Gold Certification.

$7 \quad$ It is generally accepted within the building industry that the construction and operation of buildings contributes as much as $40 \%$ of all greenhouse gas emissions globally.

8 My accreditation was granted through the USGBC since the Canadian Green Building Council did not exist at the time. Although the project's accreditation process was likewise initiated with the USGBC, by the time the church was completed, the Canadian GBC was established and the accreditation process was appropriately transferred and obtained through them.

9 After defining the four functions of a sacred place, Turner proceeds to employ these to undertake an analysis of theological understandings and the design of sacred spaces within the Semitic religions.

The church property was located on the north side of Sheppard Avenue and although redevelopment on the south side, which was closest to the east-west major highway traversing Toronto had already begun, it would be decades or even longer before this process would come to its logical conclusion.

A total of six distinct design iterations were explored prior to arriving at the final design prompting Father Stephen Dunn to comment on our flexibility, stamina, and resilience as a design team.

Having a dark mass directly inside of a glass wall was a recognized strategy to harvest and store passive solar energy. For a more detailed explanation of how it works, visit https: / www.archdaily.com/946732/how-does-a-trombe-wall-work (accessed on 1 December 2021).

The Passionists would spend half of the year preaching missions to the parishes near and afar and during the other half, would remain in the monastery tending to their properties, giving retreats, and praying the office.

Every new building project in Toronto is required to undergo a site plan approval's process where city departments such as planning, urban design, urban forestry, transportation, and utilities get a chance to review and comment on the design. Final approval only comes once all of their comments are incorporated into the scheme. This process can often take several months to complete and result in several more design iterations.

https:/ / web.archive.org/web/20111214134948/http://gsc.nrcan.gc.ca/paleochron/17_e.php (accessed on 1 December 2021).

'Narthex' is the liturgical word used to describe the lobby space of the church. It was here during the early years of Christianity that catechumens would receive instruction in the faith. Until they had been baptised, they would not be allowed to enter the worship space and participate with the faithful in the sacramental liturgies.

St. Gabriel's was the first building in Toronto and the first worship space in Canada to achieve the Canadian Green Building Council's LEED Gold Certification. It was also recipient of the 2007 Toronto Green Design Award among other accolades and has been widely published.

18 The neo-gothic style of church architecture emerged in Canada in the mid-nineteenth century and remained the dominant style until after World War II.

For information refer to https:/ / en.wikipedia.org/wiki/H\%C3\%BCgelkultur (accessed on 1 December 2021) and other websites.

\section{References}

Angyal, Andrew, John Grim, and Mary Evelyn Tucker. 2019. Thomas Berry: A Biography. New York: Columbia University Press.

Berry, Thomas, and Brian Swimme. 1992. The Universe Story: From the Primordial Flaring Forth to the Ecozoic Era: A Celebration of the

Unfolding of the Cosmos. San Francisco: Harper.

Berry, Thomas. 1988. The Dream of the Earth. San Francisco: Sierra Club Books.

Berry, Thomas. 1999. The Great Work: Our Way into the Future. New York: Bell Tower.

Dowd, Michael. 1991. Earthspirit: A Handbook for Nurturing Ecological Christianity. Mystic: Twenty-Third Publications.

Dunn, Stephen. 2010. Cosmic Symbolic Transformations: Religious Architecture \& the Epic of Evolution. Ecopsychology 31.

Krueger, Frederick W. 2002. A Cloud of Witnesses: The Deep Ecological Legacy of Christianity, 4th ed. Oxford: Oxford Publication Department, Religious Campaign for Forest Conservation.

Rochon, Lisa. 2006. Seeing the Light on Sheppard. Toronto Globe and Mail, May 10.

Turner, Harold W. 1979. From Temple to Meeting House, The Phenomenology and Theology of Places of Worship. The Hague: Mouton. 